\title{
Not Like the Others: Applying the Fair Labor Standards Act to the Sharing Economy
}

\author{
Erica E. McCabe*
}

\section{INTRODUCTION}

Society's transition away from the 20th Century Industrial Era is largely represented by the mass digitization of our daily lives. As we modernize, so too has our method of consumption. Today, equipped only with a smartphone, modern consumers can access a wide variety of goods and services. With the click of a button, consumers can catch a ride home using Uber, ${ }^{1}$ Turo, ${ }^{2}$ or Lyft; ${ }^{3}$ book a swanky loft in Brazil using Airbnb ${ }^{4}$ or VRBO; ${ }^{5}$ rent designer clothes from Rent the Runway; ${ }^{6}$ or have dry-cleaning picked up with TaskRabbit. ${ }^{7}$

These services all form part of the larger "sharing economy." Heralded as one of the "10 Ideas That Will Change the World," the sharing economy comprises one of the fastest growing markets in the United States. ' In fact, approximately one quarter of the population in the United States, United Kingdom, and Canada engages in some form of

\footnotetext{
* J.D. Candidate, 2017, University of Kansas School of Law; B.A., 2011, University of Kansas. I extend thanks to Professor Elinor P. Schroeder, Professor Joyce Rosenberg, Mary Kate McWhirter, and the members of the Kansas Law Review for their thoughtful review of this Comment. I would also like to thank my family and friends for all of their patience. Above all else, I would like to thank my husband, Ryan, for his unwavering love and support.

1. See UBER, https://www.uber.com/?exp=home_signup_form (last visited Sept. 25, 2016).

2. See TURO, https://turo.com (last visited Sept. 25, 2016).

3. See LYFT, https://www.lyft.com (last visited Sept. 25, 2016).

4. See AIRBNB, https://www.airbnb.com (last visited Sept. 25, 2016).

5. See VRBO, https://www.VRBO.com (last visited Sept. 25, 2016).

6. RENT THE RUNWAY, https://www.renttherunway.com (last visited Sept. 25, 2016).

7. See TASKRaBbit, https://www.taskrabbit.com (last visited Sept. 25, 2016).

8. Rachel Botsman, The Sharing Economy Lacks a Shared Definition, FAST COMPANY (Nov. 21, 2013, 7:30 AM) https://www.fastcoexist.com/3022028/the-sharing-economy-lacks-a-shareddefinition\#8 (citing Bryan Walsh, 10 Ideas That Will Change the World: Today's Smart Choice: $\begin{array}{lllll}\text { Don't Own. Share, } & \text { TIME } & \text { (Mar. } & \text { 17, }\end{array}$ http://content.time.com/time/specials/packages/article/0,28804,2059521_2059717,00.html).

9. Stephen Ufford, The Future of the Sharing Economy Depends on Trust, ForBES (Feb. 10, 2015, 9:00 AM), http://www.forbes.com/sites/theyec/2015/02/10/the-future-of-the-sharingeconomy-depends-on-trust/.
} 
the sharing economy. ${ }^{10}$ Unfortunately, current labor and employment laws do not adequately account for the new types of employment relationships formed within the fast-growing sharing economy.

Online marketplaces where technological platforms facilitate peerto-peer transactions create a lot of legal uncertainty in the employment law context. Workers who engage in these markets form employment relationships that take on characteristics of both entrepreneurialism and the employer-employee relationship. The United States Supreme Court has long noted the potential for conflict with ambiguous employment relationships. In NLRB v. Hearst Publications, Inc., the Court wrote, "Few problems in the law have given greater variety of application and conflict in results than the cases arising in the borderland between what is clearly an employer-employee relationship and what is clearly one of independent entrepreneurial dealing." " Whether by coincidence or foresight, the majority in Hearst aptly diagnosed one of the largest problems facing American labor and employment law today: the classification of sharing economy workers who exist in the borderland between employees and independent contractors. Thus, the time has come to modernize outdated employment classifications and reimagine our traditional notions of employment relationships to encompass the new, rapidly growing workforce within the sharing economy.

This Comment will confront the legal ambiguity that arises when the Fair Labor Standards Act ("FLSA") is applied to the employment relationships created within the sharing economy. This Comment also proposes a legislative solution to bring the FLSA into the modern era of employment law. Part II.A of this Comment will examine the creation of the FLSA and its application to traditional employment relationships. Part II.B will address collaborative consumption and the rise of the sharing economy. This section will also explore the peer-to-peer business model through a case study of Uber. Part III.A addresses the vast policy implications of classifying sharing economy workers as traditional employees under the FSLA. Part III.B proposes two possible legislative solutions that would modernize the FLSA employment classifications through the addition of a "dependent contractor" employment classification, or alternatively, the addition of a peer-to-peer

10. Id. (citing Jeremiah Owyang, Sharing is the New Buying: How to Win in the Collaborative Economy, SLIDESHARE 15 (Mar. 2, 2014), http://www.slideshare.net/jeremiah_owyang/sharingnewbuying).

11. 322 U.S. 111, 121 (1944), overruled in part by Nationwide Mut. Ins. Co. v. Darden, 503 U.S. 318, 324 (1992). 
market exemption.

\section{BACKGROUND}

Before addressing the proposed methods for classifying sharing economy workers it is important to understand the current climate of employment classifications under the Fair Labor Standards Act ("FLSA" or "Act"). This Act governs the wage and hour requirements for public or private workers classified as "employees" under the Act's definition. ${ }^{12}$ No clear precedent has been established for the treatment of sharing economy workers under the FLSA. In fact, one judge referred to this classification debacle as a situation in which the jury will be given "a square peg and asked to choose between two round holes."13 This section will discuss the history of the FLSA, the classification of employment relationships under the FLSA, and the rise of collaborative consumption through the sharing economy.

\section{A. The Creation and Application of the FLSA}

The history of the American worker is wrought with tales of abuse and oppression. ${ }^{14}$ From slave labor to the exploitation of women, children, and people of color, early-American employers were rarely held accountable for the gross mistreatment of their workforce. ${ }^{15}$ In an attempt to remedy this misconduct, Congress created the Department of Labor with the purpose of "foster[ing], promot[ing], and develop[ing] the welfare of the wage earners of the United States." also charged with improving the working conditions of these wage earners and "advanc[ing] their opportunities for profitable employment." "17 To ensure compliance, Congress empowered the Secretary of Labor to: (1) "bring an action by or on behalf of any employee;" ${ }^{\prime 18}$ (2) impose civil penalties; $;^{19}$ and (3) seek injunctive relief

\footnotetext{
12. 29 U.S.C. $\S \S 201-219$ (2012 \& Supp. II 2014); see also Wage \& Hour Div., Fair Labor Standards Act, U.S. DEP'T OF LABOR, https://www.dol.gov/whd/flsa/ (last visited Sept. 20, 2016).

13. Cotter v. Lyft, Inc., 60 F. Supp. 3d 1067, 1081 (N.D. Cal. 2015).

14. See Edward Pessen, Chapter 2 Builders of the Young Republic, U.S. DEP'T OF LABOR, http://www.dol.gov/dol/aboutdol/history/chapter2.htm (last visited Sept. 20, 2016).

15. See id.

16. 29 U.S.C. $\S 551$ (2012).

17. Id.

18. 29 U.S.C. $\S 216$ (c) (2012).

19. $\S 216(\mathrm{e})(1)(\mathrm{A})-(\mathrm{e})(2)$.
} 
against unpaid wages due to the employee. ${ }^{20}$ The Department of Labor's Wage and Hour Division was established to further combat these abusive labor practices and to handle the administration and enforcement of various employment laws covering nearly "all private, [] [s]tate, and local government employment." ${ }^{21}$ More specifically, the Wage and Hour Division's mission is to "promote and achieve compliance with labor standards to protect and enhance the welfare of the Nation's workforce." $" 22$

The Fair Labor Standards Act of 1938 was signed into law at the tail end of the Great Depression. This Act imposed new laws to eliminate some of the grueling labor conditions suffered by American workers. ${ }^{23}$ Moreover, the purpose of the FLSA was to:

[R]aise substandard wages and to give additional compensation for overtime work as to those employees within its ambit, thereby helping to protect this nation "from the evils and dangers resulting from wages too low to buy the bare necessities of life and from long hours of work injurious to health." 24

Today, in keeping with legislative intent, the FLSA "establishes minimum wage, overtime pay, recordkeeping, and child labor standards affecting full-time and part-time workers in the private sector and federal, state, and local governments." 25

In part, the FLSA defines the scope of employment relationships. ${ }^{26}$ However, the Act only protects workers who can be classified as an "employee" under the broad FLSA definition. ${ }^{27}$ The FLSA defines the term "employee" as "any individual employed by an employer." 28 An "employer" is defined as "any person acting directly or indirectly in the

20. 29 U.S.C. $§ 217$ (2012).

21. Wage and Hour Division History, U.S. DEP'T OF LABOR, https://www.dol.gov/whd/about/history/whdhist.htm (last visited Sept. 20, 2016).

22. Wage and Hour Division Mission Statement, U.S. DEP'T OF LABOR, https://www.dol.gov/whd/about/mission/whdmiss.htm (last visited Sept. 20, 2016).

23. See 29 U.S.C. $§ 202$ (2012).

24. United States v. Rosenwasser, 323 U.S. 360, 361 (1945) (citing S. REP. No. 75-884, at 4 (1937)).

25. U.S. Dep'T of Labor, Wage \& Hour Div., Handy Reference Guide to the Fair LABOR STANDARDS ACT (Nov. 2014), https://www.dol.gov/whd/regs/compliance/wh1282.pdf.

26. See id. at 2.

27. See U.S. Dep't of Labor, Wage \& Hour Div., Administrator's Interpretation No. 2015-1, at 3 (July 15, 2015), https://www.dol.gov/whd/workers/Misclassification/AI-2015_1.pdf [hereinafter Administrator's Interpretation].

28. 29 U.S.C. $§ 203(e)(1)(2012)$. 
interest of an employer in relation to an employee." ${ }^{29}$ The term "employ" or "to suffer or permit to work" 30 was purposely drafted to create the broadest coverage possible." In practice, "[t]he Supreme Court "has consistently construed the Act "liberally to apply to the furthest reaches consistent with congressional direction," recognizing that broad coverage is essential to accomplish the [Act's] goal.",32

1. Defining the Employment Relationship

The FLSA definitions of employ, employee, and employer are important for two reasons. First, these definitions determine the scope of the employment relationship under the Act. ${ }^{33}$ Second, these definitions "provide the basis for distinguishing between employees and independent contractors." 34 Independent contractors are often described as economically independent workers "who are operating a business on their own." 35 Under the FLSA, any worker who is "economically dependent on the employer, regardless of skill level" is deemed an employee. ${ }^{36}$ However, because the FLSA defines "employ" so broadly, most workers are deemed employees under the Act. ${ }^{37}$

Employers may not escape the broad application of the FLSA "suffer or permit to work" standard by contract because "[e]conomic realities, not contractual labels, determine employment status for the remedial purposes of the FLSA." 38 It is also important to note that workers classified as employees may not waive their classification status, or the rights conferred by that status, under the FLSA. ${ }^{39}$ This is true even when

\footnotetext{
29. $§ 203(d)$.

30. $\S 203(\mathrm{~g})$.

31. See United States v. Rossenwasser, 323 U.S. 360, 362-63, 363 n.3 (1945); Nationwide Mut. Ins. Co. v. Darden, 503 U.S. 318, 326 (1992).

32. Administrator's Interpretation, supra note 27, at 3 (quoting Tony \& Susan Alamo Found. v. Sec'y of Labor, 471 U.S. 290, 296 (1985)).

33. Id.

34. Id.

35. Id. at 4 .

36. Id.

37. Id. at 2 .

38. Real v. Driscoll Strawberry Assocs., Inc., 603 F.2d 748, 755 (9th Cir. 1979). See also Rutherford Food Corp. v. McComb, 331 U.S. 722, 729 (1947) ("Where the work done, in its essence, follows the usual path of an employee, putting on an 'independent contractor' label does not take the worker from the protection of the Act."); Usery v. Pilgrim Equip. Co., 527 F.2d 1308, 1315 (5th Cir. 1976) (holding that "[n]either contractual recitations nor subjective intent can mandate the outcome in these cases. Broader economic realities are determinative.").

39. Brooklyn Sav. Bank v. O’Neil, 324 U.S. 697, 708 (1945).
} 
a worker desires to be classified as an independent contractor. ${ }^{40}$

\section{The Evolution of Employment Classification Tests}

Throughout the evolution of federal employment law, courts have relied on two general tests to determine whether a worker is an employee or an independent contractor: [1] the common law control test, and [2] the economic realities test. The adoption of the modern economic realities test is indicative of the FLSA's desire to capture more workers in their definition of an employee. ${ }^{41}$

\section{a. The Common Law Control Test}

Prior to the creation of the FLSA, courts primarily applied the common law "control test" to determine if an employment relationship existed. ${ }^{42}$ The control test was derived from the general common law of agency. ${ }^{43}$ When using this test, courts were only required to consider the level of control that was exerted by the employer over the employee. ${ }^{44}$ More specifically, the control test looked at "whether or not the 'employer' retains the right to control the manner and means by which the result is to be accomplished."

Various iterations of the common law control test are still being used today. Governmental agencies like the IRS and the National Labor Relations Board, for example, still use similar variations of the common law test. Yet, despite its popularity, Congress declined to extend the common law control test in the FLSA. ${ }^{46}$ Instead, Congress focused on

40. Brennan v. Partida, 492 F.2d 707, 709 (5th Cir. 1974) (establishing that a worker may still be classified as an employee under the FLSA when "the parties had no intention of creating an employment relationship ... [because] the FLSA does not turn on subjective intent").

41. See United States v. Rossenwasser, 323 U.S. 360, 362-63 (1945) (stating that "[a] broader or more comprehensive coverage of employees ... would be difficult to frame.”).

42. Administrator's Interpretation, supra note 27, at 3.

43. See NLRB v. United Ins. Co. of Am., 390 U.S. 254, 256 (1968); Cmty. for Creative NonViolence v. Reid, 490 U.S. 730, 751 (1989); Jeffrey E. Dilger, Pay No Attention to the Man Behind the Curtain: Control as a Nonfactor in Employment Status Determinations Under FedEx Home Delivery v. NLRB, 26 A.B.A. J. LAB. \& EMP. L. 123, 123-24 (2010) (citing FedEx Home Delivery v. NLRB, 563 F.3d 492, 495 (D.C. Cir. 2009)).

44. Dilger, supra note 43, at 126.

45. Clayton Halunen, Summary of Tests Used for Determining Worker Status (2010) (emphasis added),

http://www.americanbar.org/content/dam/aba/administrative/labor_law/meetings/2010/annualconfer ence/021.authcheckdam.pdf (presented at the American Bar Association's Fourth Annual Section of Labor and Employment Law Conference).

46. See Walling v. Portland Terminal Co., 330 U.S. 148, 150-51 (1947). 
the "broader economic realities of the working relationship."

b. The Economic Realities Test

When determining whether an employment relationship has been formed under the FLSA, courts now look to the broad economic realities of the employment relationship. ${ }^{48}$ Created by federal courts, this economic realities test questions "whether the worker is economically dependent on the employer or in business for him or herself." 49 This multi-factorial test requires the court to consider: [1] "the extent to which the work performed is an integral part of the employer's business;" [2] "the worker's opportunity for profit or loss depending on his or her managerial skill;" [3] "the extent of the relative investments of the employer and the worker;" [4] "whether the work performed requires special skills and initiative;" [5] "the permanency of the relationship;" and [6] "the degree of control exercised or retained by the employer."

While not exhaustive, these factors should be "liberally construed to provide broad coverage for workers." ${ }^{, 51}$ Because no single factor may be used to establish existence of an employer-employee relationship under the economic realities test, ${ }^{52}$ the control element must not be considered determinative. ${ }^{53}$ Similarly, an employment classification determined under the common law control test must not be considered determinative under the FLSA. ${ }^{54}$ The Supreme Court in Walling v. Portland Terminal Co. explained:

[I]n determining who are "employees" under the Act, common law employee categories or employer-employee classifications under other statutes are not of controlling significance. This Act contains its own definitions, comprehensive enough to require its application to many persons and working relationships, which prior to this Act, were not deemed to fall within an employer-employee category.

\footnotetext{
47. Administrator's Interpretation, supra note 27, at 3.

48. See, e.g., Tony \& Susan Alamo Found. v. Sec'y of Labor, 471 U.S. 290, 301 (1985); Usery v. Pilgrim Equip. Co., 527 F.2d 1308, 1315 (5th Cir. 1976); see also Goldberg v. Whitaker House Coop., Inc., 366 U.S. 28, 33 (1961).

49. Administrator's Interpretation, supra note 27, at 2.

50. Id. at 4 .

51. $I d$.

52. Id. at 2,4

53. Id. at 2 .

54. Walling v. Portland Terminal Co., 330 U.S. 148, 150 (1947).

55. Id. at 150-51 (citations omitted) (first citing NLRB v. Hearst Publ'ns, Inc., 322 U.S. 111,
} 
Furthermore, "the factors themselves should not be applied in a mechanical fashion." "indicators of the broader concept of economic dependence," should consider each factor as it relates to the others and avoid applying the factors as a checklist. ${ }^{58}$

\section{i. The Department of Labor Administrator's Interpretation}

Given the growing number of employees misclassified as independent contractors, the Department of Labor Wage and Hour Division published an Administrator's Interpretation ("Interpretation") regarding the identification of misclassified employees. ${ }^{59}$ This Interpretation offers guidance on the correct application of the FLSA's economic realities test when determining whether to classify a worker as an employee or an independent contractor. ${ }^{60}$

The clear emphasis of this Interpretation is the broad application of the FLSA "suffer or permit" standard. ${ }^{61}$ Generally speaking, under this interpretation an employee is someone who is "economically dependent on the employer," while an independent contractor is "in business for him or herself." ${ }^{2}$ The Interpretation also explained the correct application of each economic realities factor. ${ }^{63}$ These explanations will be discussed in reference to a case study later on in this article. ${ }^{64}$

\section{B. The Rise of Collaborative Consumption}

As society transitioned away from the passive consumerism of the $20^{\text {th }}$ Century "Industrial Economy," it has moved towards a "Collaborative Economy" fueled by innovation, efficiency, and trust. ${ }^{65}$ The term, "Collaborative Consumption," refers to "[ $t]$ he reinvention of

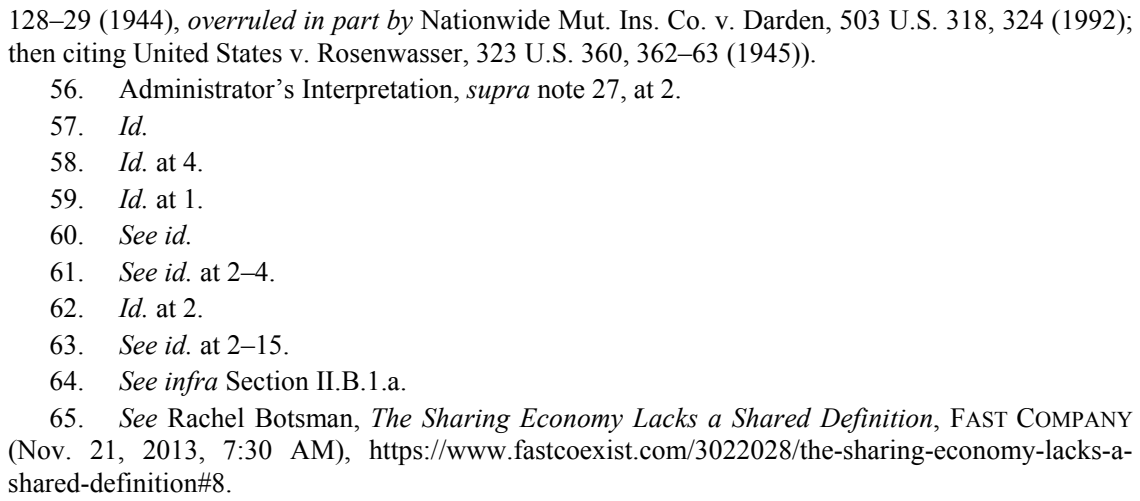


traditional market behaviors - renting, lending, swapping, sharing, bartering, gifting - through technology, taking place in ways and on a scale not possible before the [I]nternet." a "system of decentralized networks and marketplaces that unlocks the value of underused assets by matching needs and haves, in ways that bypass traditional middlemen." ${ }^{, 67}$ While innovative, this concept of collaborative consumption is not new to the industrialized world. Websites that allow for the redistribution of underused assets like Craigslist ${ }^{68}$ and eBay, ${ }^{69}$ were introduced to the general public in $1995 .^{70}$ Over a decade later, companies offering more "on-demand" services like Uber, $^{71}$ Airbnb, ${ }^{72}$ and TaskRabbit ${ }^{73}$ started popping up in the form of mobile apps. The vast growth of this industry implies a definitive paradigm shift in the way we access goods and services. ${ }^{74}$

Arun Sundararajan, a professor at New York University's Stern School of Business, broke down four of the key factors that have sparked growth within the sharing economy. ${ }^{75}$ First, Sundararajan explained that during the last decade, "[t]he consumerization of digital technologies" has shifted the focus of "information technologies" from business-driven models to individual-centric ones (e.g., creation of social media). ${ }^{76}$

66. Rachel Botsman, Defining the Sharing Economy: What Is Collaborative Consumptionand What Isn't?, FAST COMPANY (May 27, 2015, 6:15 AM), https://www.fastcoexist.com/3046119/defining-the-sharing-economy-what-is-collaborativeconsumption-and-what-isnt\#1.

67. $I d$.

68. See CRAIGSLIST, https://www.craigslist.org/about/factsheet (last visited Sept. 19, 2016).

69. See Our Company, EBAY, https://www.ebayinc.com/our-company/ (last visited Sept. 19, 2016).

70. See CRAIGSLIST, http://www.craigslist.org/about/factsheet (last visited Sept. 19, 2016); Our History, EBAY, https://www.ebayinc.com/our-company/our-history/ (last visited Sept. 19, 2016).

71. See UBER, https://www.uber.com/our-story/ (last visited Sept. 19, 2016) (founded in 2008).

72. See About Us, AIRBNB, https://www.airbnb.com/about/about-us (last visited Sept. 19, 2016) (founded in 2008).

73. Brian Solomon, TaskRabbit Founder Steps Down As CEO After Eight Years, ForBES (Apr. 14, 2016, 3:12 PM), http://www.forbes.com/sites/briansolomon/2016/04/14/taskrabbitfounder-steps-down-as-ceo-after-eight-years/\#c0166f05ae8e (founded in 2008).

74. Rachel Botsman, The Sharing Economy Lacks a Shared Definition, FAST COMPANY (Nov. 21, 2013, 7:30 AM), http://www.fastcoexist.com/3022028/the-sharing-economy-lacks-a-shareddefinition\#8.

75. See The Power of Connection: Peer-to-Peer Businesses Before the H. Comm. on Small Bus., $113^{\text {th }}$ Cong. 1 (2014) (written testimony of Arun Sundararajan, Professor and NEC Faculty Fellow, NYU Stern School of Business, and Head of Social Cities Initiative, NYU Center for Urban Science and Progress), http://smallbusiness.house.gov/uploadedfiles/1-152014_revised_sundararajan_testimony.pdf [hereinafter Sundararajan Written Testimony].

76. Id. at 3 . 
Second, Sundararajan credited the "emergence of "digital institutions.",77 These technology-based platforms make the sharing economy possible by "facilitat[ing] economic exchange in the same way that economic institutions historically have done."78 Third, Sundararajan explained that "[u]rbanization and globalization" have impacted the popularity of this sharing economy. ${ }^{79}$ Because more people are moving into cities, space is becoming more limited. ${ }^{80}$ Thus, city dwellers are beginning to engage in "natural "sharing economies" by bringing people together to share assets and space. ${ }^{81}$ Finally, Sundararajan points out that "[e]cological and resource considerations" are becoming increasingly popular. ${ }^{82}$ By engaging in the sharing economy, people can live "asset-light," and consume fewer resources, thereby lowering their carbon footprint. ${ }^{83}$

\section{The Sharing Economy}

Now officially listed in the Oxford Dictionaries, the sharing economy is defined as "[a]n economic system in which assets or services are shared between private individuals, either free or for a fee, typically by means of the Internet." ${ }^{~} 44$ This relatively new and rapidly expanding economy thrives on the theory that "access trumps ownership" in a lot of ways. ${ }^{85}$ As the industrial era becomes a relic of the past, and we move further into a "networked society," people will become increasingly dependent on technological platforms that facilitate peer-to-peer exchanges. ${ }^{86}$

From a technical perspective, the term "sharing economy," refers to a network of technological platforms that facilitates peer-to-peer transactions. This network comprises three essential components: [1] entrepreneurs, [2] consumers, and [3] the platform, itself. ${ }^{87}$

\footnotetext{
77. Id at 4.

78. Id.

79. See id.

80. See id.

81. Id.

82. See id.

83. Id.

84. Sharing Economy, OXFORD DICTIONARIES,

http://www.oxforddictionaries.com/us/definition/american_english/sharing-economy (last visited Sept. 19, 2016).

85. The Rise of the Sharing Economy, ECONOMIST (Mar. 9, 2013), http://www.economist.com/news/leaders/21573104-internet-everything-hire-rise-sharing-economy. 86. Arun Sundararajan, Opinion, A Safety Net Fit for the Sharing Economy, Fin. TIMES (June 23, 2015), https://www.ft.com/content/b1d854de-169f-11e5-b07f-00144feabdc0.

87. Sundararajan Written Testimony, supra note 75 , at 2.
} 
Entrepreneurs supply goods and services to the platforms, or marketplaces. ${ }^{88}$ Consumers are those who purchase these goods or services from the entrepreneurs. ${ }^{89}$ The platform is a "person-to-person marketplace[] which facilitate[s] the exchange of goods and services between [entrepreneurs and consumers]." ${ }^{90}$ Typically, these platforms are also responsible for collecting and distributing payments, often charging a commission on the exchange. ${ }^{91}$

a. The Peer-to-Peer Business Model: A Case Study of Uber

Uber is a San Francisco tech company that was founded in $2008 .^{92}$ The company's peer-to-peer business model utilizes a technological platform to engage consumers and entrepreneurs in ridesharing. ${ }^{93}$ Offering services that closely resemble taxi or other car services, the company asserts that they increase the accessibility of cities by connecting riders to drivers through their apps. ${ }^{94}$

At the end of 2014, Uber's driver base exceeded 160,000. ${ }^{95}$ More astonishingly, the number of registered Uber drivers has "doubled every six months for the last two years." "96 While approximately $38 \%$ of Uber drivers do not hold any other form of employment, the majority of Uber drivers also engage in either full-time or part-time employment outside of Uber. ${ }^{97}$

\section{i. From an Entrepreneur's Perspective}

For the entrepreneur (i.e. driver), Uber imposes three requirements: [1] all drivers must be twenty-one years old with a personal driver's license; [2] each driver's car must be a 2001 model year or newer (some cities require a 2006 model year or newer); and [3] all drivers must pass

\footnotetext{
88. Id.

89. See id.

90. Id.

91. Id.

92. UBER, https://www.uber.com/our-story/ (last visited Sept. 19, 2016).

93. See id.

94. See id.

95. Brian Solomon, The Numbers Behind Uber's Exploding Driver Force, ForBES (May 1, 2015, 12:27 PM), http://www.forbes.com/sites/briansolomon/2015/05/01/the-numbers-behind-ubersexploding-driver-force/.

96. Id.

97. See id.
} 
a background check. ${ }^{98}$ Once approved, Uber drivers can use the Uber mobile application ("app") to accept rides from local Uber subscribers. 99 Uber allows drivers to choose their own schedules and reports that drivers earn an average of $\$ 19.04$ per hour. ${ }^{100}$ Uber also provides its drivers with various amounts of insurance (depending on whether they are "available" to pick up rides, "en route" to pick up a rider, or on their trips). ${ }^{101}$

\section{ii. From a Consumer's Perspective}

For the consumer, the company's services are available exclusively through an online app that subscribers can access with a computer or a mobile device. ${ }^{102}$ Once the app is downloaded, Uber requires the user to input their personal information and payment information. ${ }^{103}$ After the registration process is complete, the user may request a ride, ${ }^{104}$ and that order is offered to available Uber drivers in the area. ${ }^{105}$ Once a ride has been requested by an Uber subscriber and accepted by an Uber driver, the subscriber can track the location of the car on her mobile device. ${ }^{106}$ Uber subscribers pay for their rides via Uber's app. ${ }^{107}$

\section{iii. The Model}

Uber is wholly responsible for setting ride fares, and these rates fluctuate during "peak demand times." 108 Uber charges approximately $20 \%$ commissions on each ride (although this number is lower in some cities). ${ }^{109}$ Uber uses the revenue from these commissions to cover

\footnotetext{
98. See Driving Jobs vs. Driving with Uber, UBER, https://www.uber.com/driver-jobs (last visited Sept. 23, 2016).

99. See id. (stating the driver may use the "Uber app to find riders" in their area).

100. Id.

101. Id.

102. See Sign Up to Ride, UBER, http://www.uber.com/ride (last visited Sept. 23, 2016).

103. Id.

104. See Ride, UBER, https://www.uber.com/ride (last visited Sept. 23, 2016).

105. See Putting Drivers First: Accepting Trip Requests, UBER, https://www.uber.com/drive/partner-app/ (last visited Sept. 23, 2016).

106. Ride, UBER, https://www.uber.com/ride (last visited Sept. 29, 2016). See also Aswath Damodaran, A Disruptive Cab Ride to Riches: The Uber Payoff, FORBES (June 10, 2014, 2:37 PM), http://www.forbes.com/sites/aswathdamodaran/2014/06/10/a-disruptive-cab-ride-to-riches-the-uberpayoff/.

107. See Damodaran, supra note 106.

108. Id.

109. Id.
} 
overhead and expenses for "R\&D, technology development, customer acquisition costs (including rebates to new customers), marketing[,] and the employees/infrastructure it needs in each of the cities that it operates in." 110 Uber does not own any cars, and it does not classify any of its drivers as employees. ${ }^{111}$ Because Uber operates a low-cost business model, the company likely "keep[s] a large percent[age] of its revenues as profits." 112

\section{b. Classification of Peer-to-Peer Sharing Economy Workers Under the FLSA}

As previously mentioned, workers who engage in the sharing economy often find themselves stuck in the borderland between employees and independent contractors. Like other sharing entities, Uber is currently facing a class action lawsuit that alleges the company has been misclassifying its drivers as independent contractors. ${ }^{113}$ To understand whether Uber drivers, and more specifically drivers for UberX and UberPOOL (Uber's more traditional rideshare programs), meet the FLSA definition of employee, this section will analyze how the economic realities test applies to Uber's business practices.

i. "Is the Work an Integral Part of the Employer's Business?"114

The Wage and Hour Division's Administrator's Interpretation explains that, "[i]f the work performed by a worker is integral to the employer's business, it is more likely that the worker is economically dependent on the employer."115 The Interpretation goes on to explain that an independent contractor's work is "unlikely to be integral to the employer's business." "116

Under this factor, UberX and UberPOOL drivers would likely be considered employees. Uber, as a for-profit business, makes money by

\footnotetext{
110. Id.

111. See id. ("Uber is not in the taxi business, at least in the conventional sense, since it owns no cabs and has no cab drivers as employees").

112. Id.

113. Rachel Emma Silverman, Judges Skeptical of Uber-Lyft Claims in Labor Cases, WALL STREET J. (Feb. 2, 2015, 7:21 PM), http://www.wsj.com/articles/court-rulings-may-redefine-ridesharing-drivers-1422922890.

114. Administrator's Interpretation, supra note 27, at 6.

115. Id. (first citing Rutherford Food Corp. v. McComb, 331 U.S. 722,729 (1947); then citing Donovan v. DialAmerica Mktg., Inc., 757 F.2d 1376, 1385 (3d Cir. 1985)).

116. Id.
} 
taking a commission from every Uber ride. Thus, a court would likely determine that Uber drivers are integral to Uber's business because the company is in the business of providing rides, and the drivers are an integral part of that operation.

ii. "Does the Worker's Managerial Skill Affect the Worker Opportunity for Profit or Loss?",117

This factor examines the worker's ability to earn a profit and experience a loss based on her own managerial skills. ${ }^{118}$ This factor primarily concerns whether the worker had the ability to use her judgment and managerial skills to make decisions that would affect her financial opportunities. ${ }^{119}$ This factor requires an important consideration that working more hours to increase one's income is not a showing of managerial skill under this factor of the economic realities test. $^{120}$

Applying this factor to UberX and UberPOOL drivers, it does not appear that the drivers would qualify as employees under this factor. While picking up more Uber rides and driving longer hours would certainly increase an Uber driver's income, the driver may also control her profitability by choosing better driving routes or making herself more available in areas that attract more advantageous rides. On the other hand, Uber drivers could argue that because Uber controls the rate the drivers can charge, the company exercises more managerial skill.

iii. "How Does the Worker's Relative Investment Compare to the Employer's Investment?"121

For a worker to be classified as an independent contractor under factor three, that worker must have some investment, and thus some risk of loss. ${ }^{122}$ The worker's investment is to be compared to the investment of the employer. ${ }^{123}$ "If the worker's investment is relatively minor, that suggests that the worker and the employer are not on similar footings and

\footnotetext{
117. Id. at 7 .

118. Id. See also Herman v. Express Sixty-Minutes Delivery Serv., Inc., 161 F.3d 299, 303 (5th Cir. 1998).

119. See Administrator's Interpretation, supra note 27, at 7.

120. Id.

121. Id. at 9 .

122. Id.

123. Id.
} 
that the worker may be economically dependent on the employer."124

UberX or UberPOOL drivers would likely be classified as independent contractors under this factor. These drivers are required to supply their own car, pay for their own gas, and pay for the necessary services on their vehicles. These investments are not relatively minor when compared to the investments made by Uber.

However, two cases arising out of the Tenth ${ }^{125}$ and Seventh Circuit ${ }^{126}$ Courts of Appeals may indicate that Uber drivers providing their own cars and paying for their own maintenance are not investments at all. These courts explain, "investing in tools and equipment is not necessarily a business investment or a capital expenditure that indicates that the worker is an independent contractor." 127 Thus, if an Uber driver's personal car is not considered a business investment or a capital expenditure, it is possible that a court would deem an Uber driver an employee instead of an independent contractor.

\section{iv. "Does the Work Performed Require Special Skill and Initiative?"128}

Occasionally a worker who demonstrates a high level of skill, judgment, and initiative will be considered economically independent. ${ }^{129}$ It is important to note, however, that skills, alone, are not determinative of employment status. ${ }^{130}$

Applying this factor would likely result in the classification of Uber drivers as employees because driving a car would not likely be considered a specialized skill. ${ }^{131}$ An argument could be made that Uber drivers "exercis[e] business skills, judgment, or initiative" ${ }^{132}$ when they choose which rides to accept and when they determine which routes to

\footnotetext{
124. Id.

125. See Dole v. Snell, 875 F.2d 802, 810 (10th Cir. 1989).

126. See Sec'y of Labor v. Lauritzen, 835 F.2d 1529, 1537 (7th Cir. 1987).

127. Administrator's Interpretation, supra note 27, at 10. See also Snell, 875 F.2d at 810 ("Courts have generally held that the fact that a worker supplies his or her own tools or equipment does not preclude a finding of employee status."); Lauritzen, 835 F.2d at 1537 (quoting Donovan v. Gilmor, 535 F. Supp. 154, 161 (N.D. Ohio 1982) ("The Gillmor court characterized the investment in this context to be 'large expenditures, such as risk capital, capital investments, and not negligible items or labor itself."').

128. Administrator's Interpretation, supra note 27, at 10.

129. See id.

130. Brock v. Superior Care, Inc., 840 F.2d 1054, 1060 (2d Cir. 1988).

131. See Our Nation's Highways: 2011, U.S. DeP'T TRANSP. Fed. Highway Admin., https://www.fhwa.dot.gov/policyinformation/pubs/hf/p111028/chapter4.cfm (citing that, as of 2009, there were 210 million licensed drivers in the United States) (last modified Nov. 7, 2014).

132. Administrator's Interpretation, supra note 27, at 11.
} 
drive. Unfortunately, this is probably not specialized enough to meet the high standard of an independent contractor under this factor.

v. "Is the Relationship Between the Worker and the Employer Permanent or Indefinite?",133

Under the Wage and Hour Division's guidance, an employee is a worker who has a permanent or indefinite relationship with an employer. ${ }^{134}$ This relationship demonstrates a level of economic dependence that is only present with employees. ${ }^{135}$ However, this is not to say that the absence of a permanent relationship automatically forms an independent contractor employment relationship. ${ }^{136}$ Moreover, it is important to consider whether the absence of permanence is caused by the "operational characteristics intrinsic to the industry" or "the worker['s] own business initiative." 137 However, in Superior Care, the Second Circuit explained, "neither working for other employers nor not relying on the employer as his or her primary source of income transform the worker into the employer's independent contractor." 138 Furthermore, it is important to consider whether UberX and UberPOOL drivers control their own schedules entirely. Because of this, these drivers do not likely share a permanent or indefinite relationship with Uber. However, as noted by the Second Circuit, this absence of permanence does not automatically create an independent contractor relationship. ${ }^{139}$ Rather, when applying the standard from the Second Circuit, it appears that an Uber driver's impermanent relationship with Uber is simply due to the driver's business incentives. Thus, under this factor, an Uber driver would likely be classified as an employee.

vi. "What is the Nature and Degree of the Employer's Control?"140

To be considered an independent contractor under this factor, the worker must exert control over important aspects of the work so that the

\footnotetext{
133. Id.

134. Id.

135. See id. at 11-12.

136. Id. at 12 .

137. Brock v. Superior Care, Inc., 840 F.2d 1054, 1060-61 (2d Cir. 1988).

138. Administrator's Interpretation, supra note 27, at 12; see Superior Care, 840 F.2d at 1060.

139. See Superior Care, 840 F.2d at 1060-61.

140. Administrator's Interpretation, supra note 27, at 13.
} 
worker appears to be conducting his own business. ${ }^{141}$ When considering this factor, the Third Circuit expressed, "the fact that the workers could control the hours during which they worked and that they were subject to little direct supervision was unsurprising given that such facts are typical of homeworkers and thus largely insignificant in determining their status." "142 Furthermore, a worker's ability to control his schedule is not enough to establish an independent contractor relationship. ${ }^{143}$

Using this guidance, it appears that an UberX or an UberPOOL driver would be considered an employee when applying this factor. Outside of controlling their hours and their appearance, Uber drivers cannot alter the Uber framework of service. Uber controls a large portion of the driver's business. From setting the payment rates to controlling the customer reviews, Uber holds control over the driver.

\section{ANALYSIS}

While there is certainly a need for regulation in this rapidly expanding economy, such regulations must be carefully crafted to ensure necessary consumer and worker protection while also protecting innovative entrepreneurialism. This section will discuss the policy implications of applying traditional employment classification to the peer-to-peer business model. This section also proposes two alternative legislative solutions. Both solutions aim to prevent the negative implications of maintaining a traditional employment model and to provide clarity in employment classification within the peer-to-peer sharing economy.

\section{A. Policy Implications of Classifying Sharing Economy Workers as Employees}

\section{Disadvantages}

Applying traditional labor and employment laws to the sharing economy will be detrimental to this innovative peer-to-peer business model and will likely lead to the material alteration of the industry. Such an application would harm both the sharing economy and low-income, urban communities that have the most to gain from access to asset-

\footnotetext{
141. Id. See Scantland v. Jeffry Knight, Inc., 721 F.3d 1308, 1313 (11th Cir. 2013).

142. Administrator's Interpretation, supra note 27, at 12. See Donovan v. DialAmerica Mktg., Inc., 757 F.2d 1376, 1384 (3d Cir. 1985).

143. See, e.g., Dole v. Snell, 875 F.2d 802, 806 (10th Cir. 1989).
} 
sharing programs.

a. Impact on the Sharing Economy as a Business Model

The companies that create peer-to-peer transaction platforms likely lack the infrastructure necessary to support a large number of employees. These companies that engage in the sharing economy are also not likely structured to support the minimum wage and overtime pay regulations that are imposed by employer-employee relationships under the FLSA. Forcing these companies to either reduce their control or bear the cost of "employing" every micro-entrepreneur who utilizes their platform will lead to industry-altering results.

Within the peer-to-peer business model, the platform creator is primarily responsible for facilitating a space in which people can begin transacting and collaborating. If allowed to flourish, the peer-to-peer sharing economy has the ability to foster entrepreneurialism and innovation. ${ }^{144}$ Moreover, "the relatively low-risk micro-entrepreneurship allowed by peer-to-peer business may be the first step to broader entrepreneurship, perhaps an 'on ramp' ... to freelancing or starting an independent business." 145 In addition to this potential for growth, the peer-to-peer sharing economy may also create "productivity gains" in the consumption of untapped or underutilized assets and "underutilized human capital." 146 Creating a market that is focused on the efficient use of assets and labor fundamentally increases the productivity. ${ }^{147}$

The standards, or controls, imposed by these platforms exist to ensure consistency, efficiency, and consumer protection. For example, Uber requires all of its drivers to undergo background checks before they can begin accepting ride requests. ${ }^{148}$ Similarly, Uber controls the fare rates for all of its subscribers. ${ }^{149}$ In setting these prices, Uber allows subscribers to check their "fare estimate[s]" before their trips begin. ${ }^{150}$

If companies like Uber were no longer able to impose these types of controls over their platforms without conferring all of the regulations

\footnotetext{
144. Sundararajan Written Testimony, supra note 75 , at 5.

145. Id.

146. Id.

147. Id.

148. Driving Jobs vs Driving with Uber, UBER, https://www.uber.com/driver-jobs (last visited Sept. 22, 2016).

149. See Understanding Uber Fares, UBER, https://help.uber.com/h/d2d43bbc-f4bb-4882b8bb-4bd8acf03a9d (last visited Sept. 22, 2016); Damodaran, supra note 106.

150. Understanding Uber Fares, supra note 149.
} 
imposed on employer-employee relationships, the peer-to-peer business model would likely experience a shift towards lower safety standards, loss of uniformity in price, and loss of uniformity in service. Additionally, "[r]egulatory uncertainties and concerns about liability can impede individuals from pursuing otherwise productive and profitable peer-to-peer business opportunities." ${ }^{\text {"151 }}$ Thus, while large, wellestablished peer-to-peer businesses - like Uber - may find a way to adapt and comply with these regulations, the application of these FLSA requirements will stifle innovation in smaller peer-to-peer businesses and startups.

\section{b. Impact on Low-Income Communities}

The peer-to-peer sharing economy rests in an unparalleled position to provide efficient access to goods and services in low-income communities. Historically, access to goods or services required ownership and infrastructure. ${ }^{152}$ However, the rise of the peer-to-peer sharing economy has both created the necessary infrastructure and eliminated the requirement of ownership. ${ }^{153}$

Statistically, low-income, urban communities stand to benefit the most from the growing access to peer-to-peer businesses. ${ }^{154}$ Peer-to-peer sharing economies provide access to resources that might not otherwise be available in lower-income, urban environments. ${ }^{155}$ In fact, research has shown that "ride-sharing has a "disproportionately positive effect on lower-income consumers." 156 For instance, lower-income consumers are less likely to possess the spending power required for ownership, and thus, these communities are more likely to benefit from greater

\footnotetext{
151. Sundararajan Written Testimony, supra note 75, at 6.

152. See Emily Badger, The Real Promise of the 'Sharing Economy' Is What It Could Do for the Poor, WASH. POST (Mar. 16, 2015), https://www.washingtonpost.com/news/wonk/wp/2015/03/16/the-real-promise-of-the-sharingeconomy-is-what-it-could-do-for-the-poor/ (discussing the Fraiberger \& Sundararajan article and stating: "Until now, these were goods accessed primarily through ownership. And if you couldn't afford to own them, you simply didn't use them at all.").

153. See id.

154. Samuel Fraiberger \& Arun Sundararajan, Peer-to-Peer Rental Markets in the Sharing Economy 27 (Oct. 6, 2015), http://papers.ssrn.com/sol3/papers.cfm?abstract_id=2574337\#\# (unpublished manuscript).

155. Della Bradshaw, Sharing Economy Benefits Lower Income Groups, FIN. TIMES (Apr. 22, 2015), http://www.ft.com/intl/cms/s/2/7afde9b0-d95a-11e4-a8f100144feab7de.html\#axzz3mkDyNobL.

156. Ben Schiller, How the Sharing Economy Could Help the Poorest Among Us, FAST COMPANY (Mar. 16, 2015, 11:57 AM), http://www.fastcoexist.com/3043531/how-the-sharingeconomy-could-help-the-poorest-among-us.
} 
accessibility to the sharing economy. ${ }^{157}$ In fact, data collected from Getaround, a peer-to-peer car sharing and rental service, showed that people living in lower-income communities in San Francisco were more likely to use Getaround services than people living in higher-income areas. ${ }^{158}$ Furthermore, these "[1]ower-income consumers also stand to gain the most from renting out their goods [and services] on these platforms." 159 In this context, the researchers reasoned that providing a $\$ 10.00$ Uber ride is more beneficial to a service worker than it would be to a banker. ${ }^{160}$ It seems apparent that the destruction or material alteration of the peer-to-peer industry will likely harm low-income and urban communities that rely on asset-sharing and collaborative consumption.

\section{Advantages}

Despite an employer's intentions, the misclassification of employees as independent contractors results in widespread consequences. Workers classified as independent contractors do not enjoy the same economic and social benefits that are protected by the employer-employee relationship. ${ }^{161}$ Because independent contractors are not protected by the FLSA, employers are not bound by the wage and hour requirements afforded to employees under the Act. In addition, companies that classify their workers as independent contractors save between $20 \%$ and $40 \%$ of labor costs. ${ }^{162}$ These savings coupled with the absence of protection and oversight may incentivize the misclassification of employees as independent contractors. ${ }^{163}$

a. Strict Compliance with FLSA Employment Classifications Precludes Potential for Abusive Misclassification

The Wage and Hour Division's Interpretation expressed that "[m]isclassification of employees as independent contractors is found in

\footnotetext{
157. See id.

158. Id.

159. Badger, supra note 152.

160. See id. (the article includes a parallel analogy between the benefit a waitress would receive from Uber compared to the benefit a lawyer would receive).

161. Jenna Amato Moran, Independent Contractor or Employee? Misclassification of Workers and Its Effect on the State, 28 BUFF. PUB. INT. L.J. 105, 121 (2010).

162. Id. (quoting Eileen Silverstein \& Peter Goselin, Intentionally Impermanent Employment and the Paradox of Productivity, 26 STETSON L. REV. 1, 9 (1996)).

163. See id. at 121-22.
} 
an increasing number of workplaces." ${ }^{\text {164 }}$ Employees wrongly classified as independent contractors are deprived of necessary workplace protections like "minimum wage, overtime compensation, unemployment insurance, and workers' compensation." 165 Additionally, misclassification negatively impacts the federal government by lowering tax revenues, and it harms competition within the market by creating an inherent disadvantage for businesses that use proper classifications. ${ }^{166}$

The disadvantages faced by competing businesses are compounded when considering the peer-to-peer sharing economy. Modern business models, like the one used by Uber, are profoundly advantageous when compared to a more traditional model. Because the competitive advantages and cost savings of the peer-to-peer business model are so great, there is a higher risk of abusive misclassification. By requiring strict compliance with the current FLSA employment classification structure, companies like Uber would almost certainly have to classify their workers as employees. Forcing this transition would largely eliminate the business advantages of the peer-to-peer business model, and thereby curb the incentive to misclassify employees as independent contractors.

\section{B. Legislative Recommendations}

Because employment relationships created by the peer-to-peer sharing economy do not fall neatly into either the employee or the independent contractor classification, courts are forced to apply illsuited, traditional classifications to a rapidly evolving workforce. This article proposes two legislative options to address these concerns: [1] the adoption of a third, "dependent contractor" classification under the FLSA; or alternatively, [2] the inclusion of a peer-to-peer market exemption from overtime payment requirements under the FLSA.

Both solutions address one of the fundamental concerns with classifying peer-to-peer workers as employees-FLSA overtime pay requirements. Promotion of entrepreneurialism is one of the key values in the peer-to-peer sharing economy, and fundamental to the promotion of peer-to-peer entrepreneurialism is the freedom to make choices. If peer-to-peer businesses are bound by FLSA's overtime pay requirements, they may be forced to limit the choices workers can make

164. Administrator's Interpretation, supra note 27 , at 1 .

165. Id.

166. Id. 
regarding their schedule (i.e. the amount of hours worked in one week).

1. Congress Should Include "Dependent Contractors" as a Third Employment Classification Under the FLSA

Congress should create a "dependent contractor" classification under the FLSA to encompass the modern employment relationships formed within the peer-to-peer sharing economy. The inclusion of a third employment classification would allow for the efficient and effective regulation of peer-to-peer businesses while leaving enough flexibility to foster innovation and growth.

The United States would not be the first industrialized nation to incorporate such a standard into its labor and employment laws. ${ }^{167}$ While international dependent contractor classifications are more frequently discussed in relation to collective bargaining, ${ }^{168}$ the impact of this additional classification under the FLSA would be profoundly beneficial. By adopting an intermediate employment classification, namely the dependent contractor classification, the Department of Labor would improve American labor and employment law in two ways. First, this standard would create a balance between the Department of Labor's interest in employee protection and the peer-to-peer sharing economy's interest in innovation. Second, this standard would establish a modern classification that encompasses the types of employment relationships formed within the peer-to-peer sharing economy.

\section{a. The Dependent Contractor: An International Approach}

H.W. Arthurs first introduced the notion of dependent contractors to North America in 1965. ${ }^{169}$ Borrowing the term from a Swedish writer, Arthurs opined that a new category of employment-dependent contractors-be included in Canada's labor laws on collective

167. See Mitchell H. Rubinstein, Employees, Employers, and Quasi-Employers: An Analysis of Employees and Employers Who Operate in the Borderland Between an Employer-and-Employee Relationship, 14 U. PA. J. Bus. L. 605, 629 (2012).

168. See Brian A. Langille \& Guy Davidov, Beyond Employees and Independent Contractors: A View from Canada, 21 COMP. LAB. L. \& POL'Y J. 7, 24 (1999) (noting that collective bargaining has been adopted as a "technique for redressing [the] imbalance of power" in "employment relations" in the context of Canadian public policy).

169. Justin Fox, Uber and the Not-Quite-Independent Contractor, BLOOMBERG VIEW (June 23, 2015, 11:59 AM), http://www.bloombergview.com/articles/2015-06-23/uber-drivers-are-neitheremployees-nor-contractors; see Langille \& Davidov, supra note 168, at 24. 
bargaining. ${ }^{170}$ By 1980 , the majority of Canadian provinces adopted dependent contractor classification for determining collective bargaining rights. ${ }^{171}$

Under the Ontario Labour Relations Act, a dependent contractor is defined as:

[A] person, whether or not employed under a contract of employment, and whether or not furnishing tools, vehicles, equipment, machinery, material, or any other thing owned by the dependent contractor, who performs work or services for another person for compensation or reward on such terms and conditions that the dependent contractor is in a position of economic dependence upon, and under an obligation to perform duties for, that person more closely resembling the relationship of an employee than that of an independent contractor ...

Defining "economic dependence," however, creates more of a challenge. While some Canadian jurisdictions establish a multi-factor test, ${ }^{173}$ others simply require a showing that the worker "derive[s] at least $80 \%$ of his income from the employer." " Similar intermediate employment classifications exist in Germany and Italy. ${ }^{175}$ To be considered a dependent contractor in Germany, workers must only prove that "more than $50 \%$ of [their] income [was] paid by one person or institution." 176 German artists and writers, on the other hand, are only required to prove that $33 \%$ of their income was paid by one person or institution. ${ }^{177}$

\section{b. Proposed Definition and Application of the Dependent Contractor} Classification Under the FLSA

To broaden employment classifications and incorporate a clear dependent contractor status under the FLSA, both Congress and the Department of Labor must act. First, Congress must codify a definitional standard for this employment classification under the FLSA. Congress must also establish the rights to be conferred on dependent contractors

\footnotetext{
170. Langille \& Davidov, supra note 168, at 24-25.

171. See id. at 25 .

172. Ontario Labour Relations Act, S.O. 1995, c 1, sched. A, § 1 (Can.).

173. Elizabeth Kennedy, Comment, Freedom from Independence: Collective Bargaining Rights for “Dependent Contractors,” 26 Berkeley J. EMP. \& LAB. L. 143, 154-55 (2005). See also Can. Labour Cong. (Can. Ass'n of Burlesque Entertainers, Local Union No. 1689) v. Algonquin Tavern, 1981 CanLII 812 (Can. Ont. L.R.B.).

174. Langille \& Davidov, supra note 168 , at 28.

175. Rubinstein, supra note 167 , at 629.

176. Langille \& Davidov, supra note 168, at 28 n.64 (citation omitted).

177. Id.
} 
under the FLSA. Following the codification of this standard, the Department of Labor Wage and Hour Division should amend the economic realities test to include a seventh factor addressing the level of economic dependence required to qualify as a dependent contractor.

i. Proposed Definition and Rights of a Dependent Contractor Under the FLSA

To establish a clear, unambiguous standard for dependent contractors, Congress must codify a definition of the term under the FLSA. This article proposes the inclusion of a dependent contractor classification that would closely resemble the Canadian and German models. Under the FLSA a dependent contractor would be defined as:

A person, regardless of contract, who performs work or provides services for compensation on such terms and conditions that the dependent contractor is in a position of economic dependence upon, and under an obligation to perform duties for, the other more closely resembling the relationship of an employee than that of an independent contractor.

This definition, derived from the Canadian model, focuses on the "economic dependence" of the dependent contractor. In focusing on this economic dependence, this definition captures the current peer-to-peer sharing economy workers that exist in the borderland between employee and independent contractor.

ii. Proposed Incorporation of an "Economic Dependence" Factor into the Economic Realities Test

To include a dependent contractor classification under the FLSA, the Department of Labor should incorporate a specific economic dependence factor into the existing economic realities test. This factor should only be considered when the economic realities test does not produce a clear, definitive result. To preserve the necessary portions of the status quo, preference will be given to the employee and independent contractor classifications. Thus, workers may only be classified as a dependent contractor if classification as an employee or independent contractor is impracticable given the nature of the employment relationship.

In practice, the dependent contractor classification would exist in the

178. See Ontario Labour Relations Act, S.O. 1995, c 1, sched. A, § 1 (Can.). 
space between an employee and an independent contractor. To determine whether a worker qualifies as a dependent contractor, this article proposes using a standard similar to the one used in Germany. Courts should consider whether one employer in the employment relationship paid $50 \%$ of the worker's income. If one employer has paid $50 \%$ of the worker's total income, this worker would be entitled to receive FLSA protections as a dependent contractor. By establishing this threshold, the FLSA can account for workers who casually engage in a peer-to-peer business to supplement existing income, and those that are economically dependent on the peer-to-peer transaction.

\section{iii. Proposed Benefits to be Conferred Upon Dependent Contractors}

Under the FLSA, workers who are classified as dependent contractors would be entitled to protections greater than those of an independent contractor, but less than those of an employee. This article proposes that dependent contractors should be afforded minimum wage protections, but exempted from overtime pay requirements. In practice, this is similar to the FLSA exemptions offered to workers like commissioned retail employees, domestic service workers, and taxi drivers. ${ }^{179}$

c. Possible Impacts of Including a Dependent Contractor Classification Under the FLSA

Incorporating a dependent contractor classification under the FLSA will likely result in two key benefits to the greater peer-to-peer sharing economy. First, the adoption of this third classification will promote entrepreneurialism by balancing the FLSA's interest in employee protections and the peer-to-peer sharing economy's interest in innovation. Second, the adoption of this dependent contractor classification will create a modern, ascertainable standard for employment classifications.

i. Including Dependent Contractors Under the FLSA Would Balance Employee Protection and Employer Innovation

As previously stated, the FLSA was created to protect our society "from the evils and dangers resulting from wages too low to buy the bare

179. U.S. DEP'T OF LABOR, WAGE \& HOUR Div., supra note 25, at 6. 
necessities of life and from long hours of work injurious to health." 180 Any alterations or amendments to the Act should be made in light of this goal. In keeping with this mission, the addition of a dependent contractor classification under the FLSA would balance the FLSA's interest in maintaining employee protections with the peer-to-peer sharing economy's interest in unencumbered business practices.

By providing this third classification-one that will likely encompass many of the peer-to-peer workforce-the FLSA will no longer risk destroying entrepreneurial spirit of the sharing economy. Furthermore, eliminating the overtime pay requirements for dependent contractors allows for peer-to-peer businesses to continue operating much like they do today. Companies like Uber, whose workers earn an average of $\$ 19.00$ per hour (well over the minimum wage requirements), can continue to host a peer-to-peer market place where microentrepreneurs control the amount and frequency of their work. ${ }^{181}$

\section{ii. Including Dependent Contractors Under the FLSA Would Create a \\ Reliable Standard for Employment Classifications}

By establishing a dependent contractor classification to encompass workers who engage in the peer-to-peer sharing economy, the FLSA will create a reliable standard for employment classifications. Creating a clear, reliable standard is preferential for three reasons: [1] a clear standard will reduce the number of misclassified employees; [2] a clear standard will reduce the amount of litigation arising from improperly classified employees; and [3] a clear standard for classifying employees under the FLSA will allow companies to utilize new and innovative ways to add jobs to the market.

Creating a third classification-like the dependent contractorwould likely reduce the number of misclassified employees in the peerto-peer sharing economy. Because there is no legal precedent regarding the classification of this workforce, and because existing FLSA classifications do not adequately represent the sharing economy workforce, companies are left to guess at which classification best matches their workforce. This guessing game is detrimental to both workers and employers alike because it leaves workers without a clear

\footnotetext{
180. United States v. Rosenwasser, 323 U.S. 360, 361 (1945) (quoting S. REP. No. 75-844, at 4 (1937)).

181. Maya Kosoff, Uber Just Released Its First Report on Its Drivers-Here Are the Numbers, BUS. INSIDER (Jan. 22, 2015, 10:50 AM), http://www.businessinsider.com/uber-driver-data-report2015-1.
} 
understanding of their rights, and it leaves employers vulnerable to litigation.

Similarly, a clear, easily ascertainable standard would likely reduce the amount of litigation arising out of the misclassification of workers. It is not surprising that uncertainty begets litigation. This has proven true with the recent influx of litigation concerning the classification of peerto-peer sharing economy workers. ${ }^{182}$ Class action suits brought against companies engaged in the sharing economy have become increasingly common in light of these uncertainties. ${ }^{183}$ Peer-to-peer sharing companies, like Uber, have been hit with the brunt of this litigation. ${ }^{184}$ By establishing a dependent contractor classification, the FLSA would improve employers' ability to properly classify their workforce. In establishing this new employment classification, the need for such litigation would likely plummet. Furthermore, by ensuring that proper classifications exist for all members of the workforce, the FLSA could eliminate the "square peg, round hole" dilemma faced by members of the peer-to-peer sharing economy. With a proper statutory classification scheme in place, peer-to-peer businesses would continue to have the flexibility to create new and innovative employment relationships without fear of costly lawsuits.

\section{Congress Should Establish a Peer-to-Peer Market Exception Under the FLSA}

As an alternative to the creation of a dependent contractor classification, the FLSA could establish a new exemption-the peer-topeer market exemption. The FLSA currently exempts some categories of workers from federal minimum wage, overtime pay requirements, or both. ${ }^{185}$ Generally, these exemptions are construed narrowly against the employer. ${ }^{186}$ Some of the most commonly FLSA exemptions include: [1] commissioned sales employees exemption from overtime pay; [2] computer professional's exemption from overtime pay; [3] motor carrier personnel's exemption from overtime pay; and [4] farmworkers who, in some cases, can be exempt from minimum wage and overtime

\footnotetext{
182. See Fox, supra note 169.

183. Id.

184. Id.

185. U.S. DEP'T OF LABOR, WAGE \& HOUR DiV., supra note 25, at 5-7.

186. Fair Labor Standards Act Advisor: Exemptions, U.S. DEP'T OF LAB., http://webapps.dol.gov/elaws/whd/flsa/screen75.asp (last visited Sept. 25, 2016).
} 
provisions. ${ }^{187}$ This section proposes the addition of a peer-to-peer market exemption from overtime pay and analyzes the potential impacts of this new exemption.

\section{a. The Proposed Peer-to-Peer Market Exemption}

A peer-to-peer market exemption would exclude all workers in the peer-to-peer sharing economy from access to the FLSA's overtime pay requirements. This peer-to-peer market exemption would closely resemble the six other overtime-only exemptions, which include: [1] certain commissioned retail or service employees; [2] railroad workers, taxi drivers, and various other transportation workers; [3] announcers, news editors, and some broadcasting station engineers; [4] "domestic service workers" who live with their employers; [5] movie theater workers; and [6] some farmworkers. ${ }^{188}$

Similar in its effort to limit employer's exposure to the FLSA overtime pay requirements, the peer-to-peer market exemption would apply to all workers who use technological platforms to engage in peerto-peer transactions. This exemption would not apply to workers who clearly meet the FLSA definition of employ and thereby form employeremployee relationships under the Act. Employers, for the purposes of this exemption, would be those who create and maintain the technological platforms.

To qualify for this exemption, a peer-to-peer business must show that its workforce uses a technological platform to engage in peer-to-peer transactions. Uber drivers, for example, would fall under this peer-topeer exemption. Because Uber drivers utilize Uber's technological platform to engage in peer-to-peer transactions (i.e. ridesharing), these workers would be exempted from qualifying for overtime pay under the FLSA. It is also important to note that any material change in an existing employment relationship would require a re-evaluation of the peer-topeer market exemption to ensure proper compliance.

b. Possible Impacts of Including a Peer-to-Peer Market Exemption Under the FLSA

Including a peer-to-peer market exemption under the FLSA will likely result in three primary benefits to the greater peer-to-peer sharing

187. Id.

188. U.S. DEP'T OF LABOR, WAGE \& HOUR DIV., supra note 25, at 6. 
economy. First, the adoption of this exemption will likely force peer-topeer businesses to shoulder more responsibility for self-regulating. Second, the adoption of this exemption will likely allow entrepreneurialism to flourish. Finally, the creation of a peer-to-peer market exemption will create a clear, ascertainable standard for employment classifications, thereby minimizing employers' vulnerability to lawsuits and maximizing workers' access to workplace protections.

i. Adoption of the Peer-to-Peer Market Exemption Would Give the Peer-to-Peer Sharing Economy More Power to Self-Regulate

While granting the peer-to-peer businesses more power to selfregulate seems like a recipe for abuse, these platforms are in the best position to ensure fairness and consumer safety. In his written testimony for the Congressional hearing titled, The Power of Connection: Peer-toPeer Businesses, Professor Sundararajan outlined three reasons why peer-to-peer businesses should be granted more regulating power over the peer-to-peer sharing economy. ${ }^{189}$

First, Sundararajan explained, "[t] he interests of the platforms are well aligned with facilitating safe and profitable peer-to-peer trade."190 Because the success of peer-to-peer businesses is intricately bound to the "volume and continued growth of [the] trade," these businesses are in the best position to regulate "infringing entrepreneurs and consumers.",191 Second, these platforms utilize in-depth "digital identity verification, reputation and credit scoring systems."192 Because these systems connect the platform with user's social media accounts, the platform can leverage "social capital" as a means of regulating the platform. ${ }^{193}$ Additionally, these platforms commonly use dual rating systems. ${ }^{194}$ In an economy where reputation determines profitability, these rating systems help consumers make informed decisions about which entrepreneurs to engage. ${ }^{195}$ Finally, Sundararajan noted that it is important to consider that "[n]ew forms of technology-mediated peer-to-peer business[es] are

\footnotetext{
189. Sundararajan Written Testimony, supra note 75 , at 7.

190. Id.

191. Id.

192. Id.

193. Id.

194. See Patrick J. Stewart, Why Uber Should Let People See Their Own Passenger Ratings, BUS. INSIDER (Oct. 23, 2014, 5:24 PM), http://www.businessinsider.com/reputation-and-the-sharingeconomy-2014-10 (the article discusses user ratings and "reputation data" that customers accumulate with companies such as Uber, Airbnb, Amazon, and Ebay).

195. See id.
} 
likely to continue to emerge rapidly over the coming years."196 By granting some regulating power to the peer-to-peer sharing economy, the government can shift the burden of "constantly monitoring and correcting regulatory misalignment across a wide variety of industries." 197

A peer-to-peer market exemption under the FLSA would give platforms the ability to impose self-regulations while still preserving the Department of Labor Wage and Hour Division's power to enforce minimum wage standards, create boundaries, and oversee the regulations. This type of collaborative relationship would likely support a culture of innovation and growth within both the sharing economy and the greater economy as a whole.

\section{ii. Adoption of the Peer-to-Peer Market Exemption Would Support}

Entrepreneurialism within the Peer-to-Peer Sharing Economy

Establishing a clear exemption of workers who engage in the peerto-peer sharing economy under the FLSA will reduce the pressure on peer-to-peer businesses to comply with certain wage and hour lawsnamely, overtime pay requirements. By reducing this burden, the FLSA will create a more nurturing environment within which entrepreneurialism can flourish without endangering the rights and protections of workers. Creating a clear, reliable peer-to-peer market exemption would promote entrepreneurialism and benefit the economy in two important ways.

First, this peer-to-peer market exemption will benefit small tech startups with "national ideas" by protecting them from the burden of forming traditional employer-employee relationships with every microentrepreneur that engages with their platform. For most small tech companies, the idea of "employing" possibly hundreds of microentrepreneurs is too high of a risk. Thus, small tech companies with creative ideas for the national market will be able to utilize the peer-topeer business model because they can rely on this peer-to-peer market exemption. Without this exemption, the economic burdens of the FLSA's minimum wage and overtime pay requirements, coupled with an impending fear of litigation, would be crippling.

Second, this peer-to-peer market exemption will foster entrepreneurialism on the part of the micro-entrepreneur. Because many

196. Sundararajan Written Testimony, supra note 75 , at 7.

197. Id. 
peer-to-peer businesses would not likely be able to shoulder the FLSA overtime pay requirements, micro-entrepreneurs may lose out on an opportunity to innovatively create profit. Furthermore, it is important to reiterate that the majority of micro-entrepreneurs who access these technological platforms are simply seeking the opportunity to supplement the income they receive from other full or part-time employment. ${ }^{198}$ By adopting a peer-to-peer market exemption, the FLSA will de-burden peer-to-peer businesses and promote the entrepreneurial spirit of the peer-to-peer sharing economy.

iii. Adoption of the Peer-to-Peer Market Exemption Would Provide a

Clear, Ascertainable Standard for the Classification of Employees

Similar to the potential advantages discussed in Part III.B.1, creating a clear peer-to-peer market exemption would likely reduce the number of misclassified employees in the peer-to-peer sharing economy. By offering an exemption for these workers, the FLSA will create a disincentive for the misclassification of workers in the peer-to-peer sharing economy. This exemption would also provide peer-to-peer businesses with a reasonable and economical regulation for their workforce.

Reduction of misclassification would almost certainly correlate with a reduction in the amount of litigation concerning these employment relationships. This potential impact is essential to the promotion of innovation and growth within the peer-to-peer sharing economy. Because of the growing costs, innovation will always be stifled in the face of impending litigation. Thus, the creation of a peer-to-peer market exemption is essential to fostering entrepreneurialism in the peer-to-peer sharing economy.

\section{CONCLUSION}

While misclassification of employees has been a problem for many years, the rapid expansion of the sharing economy has drawn some much-needed attention to the outdated system the FLSA uses to classify employment relationships. It is increasingly clear that the FLSA's strict binary for classifying employment relationships no longer suits the

198. See Brian Solomon, The Numbers Behind Uber's Exploding Driver Force, FoRBES (May 1, 2015, 12:27 PM), http://www.forbes.com/sites/briansolomon/2015/05/01/the-numbers-behindubers-exploding-driver-force/ (the article includes data showing that $61 \%$ of Uber drivers either have a full-time or part-time job outside of driving for the company). 
constantly evolving workforce. Thus, it is imperative that Congress enacts meaningful change to create clear and comprehensive employment classifications. Whether adopting a third employment classification or exempting peer-to-peer businesses from the FLSA overtime pay requirements, action must be taken to bring American labor and employment law into the $21^{\text {st }}$ Century. 